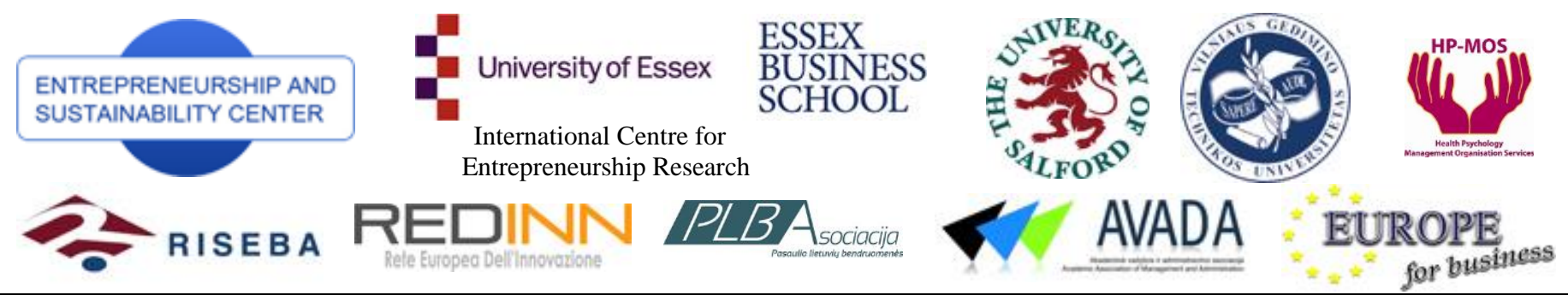

ENTREPRENEURSHIP AND SUSTAINABILITY ISSUES

ISSN 2345-0282 (online) http://jssidoi.org/jesi/

\title{
LEVEL AND SECTORS OF DIGITAL SHADOW ECONOMY: THE CASE OF LITHUANIA
}

\author{
Ligita Gasparėnienè $\dot{1}^{1}$ Rita Remeikienė ${ }^{2}$, Alius Sadeckas ${ }^{3}$, Romualdas Ginevičius ${ }^{4}$ \\ ${ }^{1,2}$ Lithuanian Institute of Agrarian Economics, Address: V. Kudirkos str. 18-2, LT 03105, Vilnius, Lithuania \\ ${ }^{3}$ Mykolas Romeris University, Address: Ateities str. 20, LT 08303, Vilnius, Lithuania \\ ${ }^{4}$ Vilnius Gediminas Technical University, Adress: Saulètekio al. 11, LT-10223 Vilnius, Lithuania \\ E-mails:1 ligitagaspareniene@laei.lt; ${ }^{2}$ rita.remeikiene35@gmail.com; ${ }^{3}$ alius@biuras.lt \\ ${ }^{4}$ romualdas.ginevicius@vgtu.lt
}

Received 20 June 2016; accepted 15 September 2016

\begin{abstract}
The fast pace of global computerization as well as the spread of online activities prompt the changes in the concept of shadow economy. Through cyberspaces, such as social networking platforms, alternative future currency systems, e-commerce, e-business systems or cyber computer games, real money (or an electronic equivalent of its value) circulates, but in most cases transactions are not accounted and do not generate taxes to the budget of a state. This article is aimed at supplementation of the traditional shadow economy estimation methodology with the indicator of digital shadow economy, and performance of the statistical analysis of the data which would allow to identify the areas with the highest scope of digital shadow economy. At present, the scope of shadow economy in Lithuania is estimated by employing one of the two methodologies - developed by the State Tax Inspectorate and by Lithuanian Free Market Institute. It should be noted that neither of these methodologies includes the elements of digital shadow economy. In theoretical level, no methodologies to cover any indicator of digital shadow economy with its relevant features have been developed so far. By employing the method of expert evaluation (with participation of 184 experts who work in the Department of Control, Lithuanian State Tax Inspectorate), the authors of this article initially estimated the scope of digital shadow economy and identified the areas with the highest scope of digital shadow economy in Lithuania over 2015. The research has revealed that more than a half of the experts have not inspected or identified any subjects illegally operating in e-space. The fact that the scopes of digital shadow economy have not still been estimated indeed burdens the development of any efficient mechanism, which would allow to identify and detect illegal economic activities in e-space.
\end{abstract}

Keywords: digital shadow economy, level of digital shadow economy, sectors of digital shadow economy, indicator of digital shadow economy, Lithuania

Reference to this paper should be made as follows: Ligita Gasparènienè, L.; Remeikienè, R.; Sadeckas, A.; Ginevičius. 2016. Level and sectors of digital shadow economy: the case of Lithuania, Entrepreneurship and Sustainability Issues 4(2): 183-197.

DOI: http://dx.doi.org/10.9770/jesi.2016.4.2(6)

JEL Classifications: E26, O17 


\section{Introduction}

For the past two decades Information and Communication Technologies have penetrated every single area of the company (Hanclova et al., 2015; Delina, Tkáč, 2015; Smaliukiene, Chi-Shiun \& Sizovaite, 2015). In spite of the fact that internet economy facilitates exchange of products and services, it also leads to emergence of digital business and digital underground economy (Holz, Engelberth \& Freiling, 2012). The spread of hardly defined economic activities online has become one of the most urgent problems in the field of economics over the last decade. According to Vlacho, Minou, Assimakopouos and Toska (2011), the soaring revenues and profits generated by illegal business practices online cause serious threats not only for consumers who take a risk of purchasing illegal commodities, but also for the entire public sector and general welfare of the state. Regardless of the necessity to diminish and control the extent of digital shadow economy, no constant statistics of its scopes have been recorded either in local or international levels. Hence, the real size of digital shadow economy remains unestimated, and the perception of how digital shadow economy can be managed and prevented stays relatively vague, which has been confirmed by some scientific studies (Holt, Blevins \& Burkert, 2010; Mayayise \& Osunmakinde, 2014).

Thus far, the studies on the issue digital shadow economy have been aimed at comparison of traditional and digital shadow economies (Smith, 2015; Vlachos et al., 2011), identification of the determinants of digital shadow consumption (Arli, Tjiptono \& Porto, 2015; Camarero, Anton \& Rodriguez, 2014; Mello, 2013; Taylor, 2012 and others.) and analysis of the issues that complicate the investigation of illegal activities in cyber space (Bossler \& Holt, 2012; Swire, 2009; Wall \& Williams, 2007). Yet the problem of the size of digital shadow economy has hardly been researched. Although the scopes of e-trade are soaring, and numerous areas of daily routines are being transferred to e-space (e-banking, e-books, exchange of goods in social networks, settlements in bitcoins, etc.), the scopes of digital shadow economy have not been estimated or separated from estimations of the scopes of traditional shadow economies. Absence of the reliable data on the scopes of digital shadow economy burdens estimation of the amounts of the revenue illegally earned in e-space, impedes assessment of the real volumes of this problem, and poses a significant challenge for law enforcement agencies to arrange its investigation and prevention.

The aim of this article - to supplement the traditional shadow economy estimation methodology with the indicator of digital shadow economy and to perform the statistical analysis of the data which would allow to identify the areas with the highest scope of digital shadow economy. To our knowledge, this type of scientific analysis has been conducted for the first time. For the fulfilment of the defined aim, the following objectives have been raised: 1) to analyse the theoretical literature on the concept of digital shadow economy and define its position in the context of traditional shadow economy; 2) to select and present the methodology of the research; 3 ) to introduce with the empirical results of the research. The methods of the research include systematic and comparative analysis of the scientific literature and expert evaluation.

\section{The concept of digital shadow economy and its position in the context of traditional shadow economy}

Scientific literature is rich in the variety of definitions and interpretations of the phenomenon of digital shadow economy. The analysis of the scientific literature has revealed that different authors define digital shadow economy considering its character (illegality), nature (operation online), purpose (economic or non-economic benefit) and the participants (consumers) involved. While defining digital shadow economy by its character, scholars interpret it as technologically advanced illegal activities online that cause serious threats for consumers, organisations and the public sector (Mello, 2013; Vlachos et al., 2011). What concerns the nature of digital shadow economy, the authors (Holz et al., 2012; Mayayise \& Osunmakinde, 2014; Smith, 2015, etc.) note remote 
(Internet-based) conduction of unofficial activities. With regard to the key purpose of digital shadow activities, the concept of digital shadow economy is frequently aligned with the terms of digital underground economy, digital black market and e-fraud, respectively meaning the performance of profit-driven unregistered activities online (Herley \& Florencio, 2010), generation of illegal revenues from online trade or service provision (Zorz, 2015), and the breach of the online-established contract (Hjort \& Lantz, 2012) or the trust between the contract parties (Amasiatu \& Shah, 2014). Finally, considering the role of consumers, digital shadow economy covers the terms of digital piracy and dysfunctional consumer behaviour online, respectively standing for the illegal or unauthorized copying/downloading of particular copyrighted content (Camarero et al., 2014; Castro, Bennett \& Andes, 2009) and consumers' actions in the Internet that violate the generally accepted norms of conduct in trade (Harris \& Daunt, 2011; Reynolds \& Haris, 2009). Considering the position of digital shadow economy in the context of traditional shadow economy, some authors state that, similarly to traditional shadow economy, it is the wrong attitude to dissociate the former from grey economy since "it is a natural element of the economic/social life and should be considered in such a context" (Schneider, Raczkowski \& Mroz, 2015: 35). In their study on shadow economy and tax evasion in the EU, Schneider et al. (2015) introduced the model of unofficial economy in the context of the whole economy. Following the model mentioned above, unofficial economy derives from four sectors of fundamental significance, i.e. agriculture, industry, services, and information and knowledge. However, the constituent of digital shadow economy is not included. With regard to significant contribution of digital shadow activities to the total scope of traditional shadow economy (according to the Government Accountability Office (GAO), various forms illegal activities online "cost the economy approximately $\$ 117.5$ billion each year" (2007: 3), this model can be expanded by incorporating the constituent of digital shadow economy (see Figure 1).

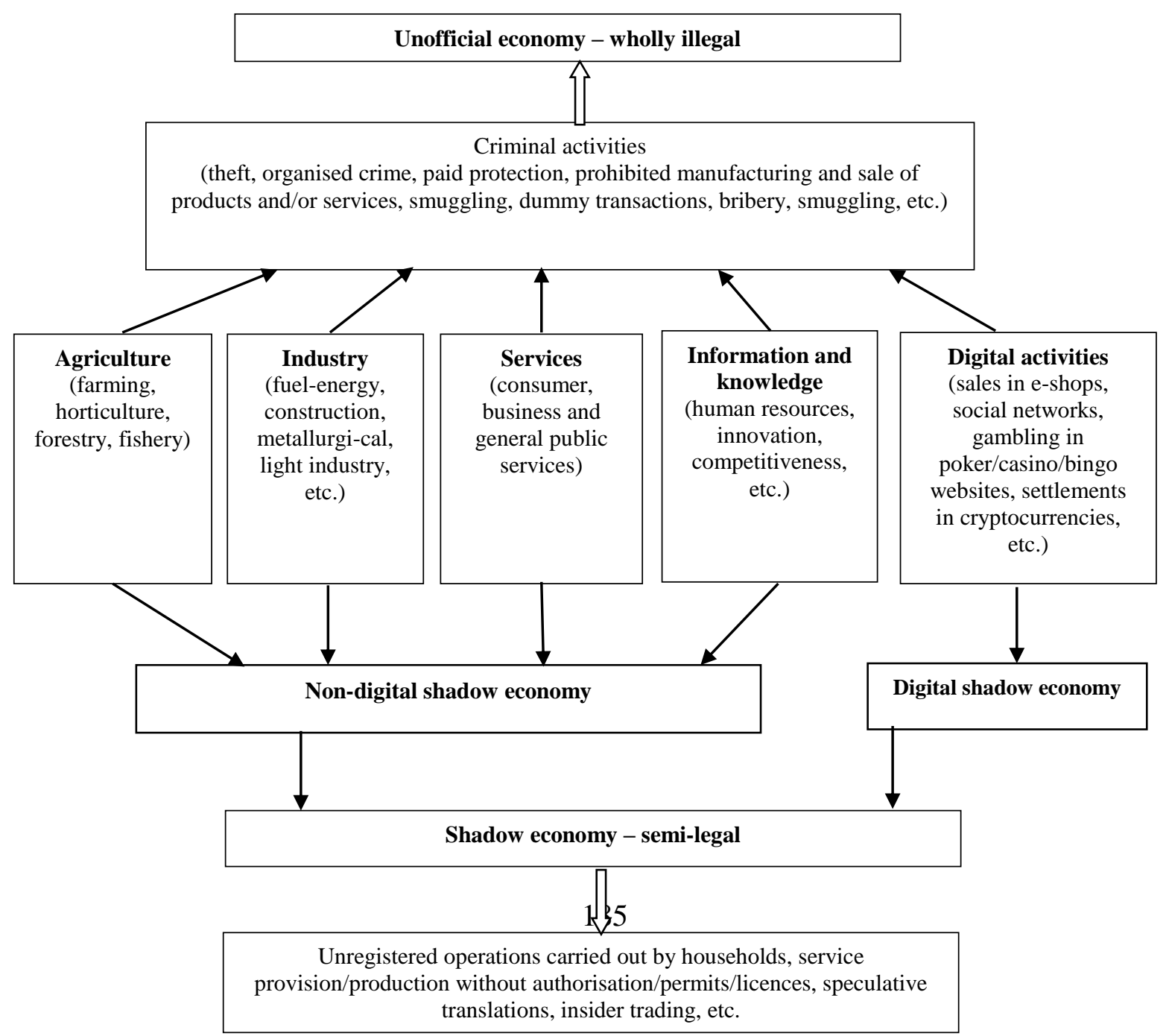




\section{The International Journal}

ENTREPRENEURSHIP AND SUSTAINABILITY ISSUES

ISSN 2345-0282 (online) http://jssidoi.org/jesi/

2016 Volume 4 Number 2 (December)

Fig.1. The position of digital shadow economy in the model of traditional shadow economy

Source: compiled by the authors with reference to Schneider et al., 2015.

Figure 1 shows that shadow (unofficial) economy (i.e. unregistered operations carried out by households, provision of services and production without registering/authorisation, permits, licences, and their inconsistent declaration, speculative translations and insider trading) derives from five fundamental sectors (agriculture, industry, services, and information and knowledge sectors representing non-digital economy, and digital activities such as sales in e-shops with exceptionally electronic settlements, gambling in poker/casino/bingo websites, gaming in e-game websites, trade in social networks, settlements in bitcoins and other cryptocurrencies, etc. representing digital shadow economy), and the sector of digital shadow economy is ponderable as the one that provides the opportunities to create value without any geographical boundaries and minimize the information gap while undertaking the decisions of a transaction.

According to Bossler and Holt (2012), lack of a universally recognised concept of digital shadow economy as well as absence of the methodologies purposefully developed to estimate its size are acknowledged as the key hindrances that complicate investigation and prevention of illegal businesses online. Thus far, the studies on the issue of shadow economy estimation have covered the comparative analysis of different traditional shadow economy estimation methods (Georgiou, 2007; Schneider \& Williams, 2013; Schneider et al., 2015), causal variables (Buehn \& Schneider, 2012; Teobaldelli, 2011; Teobaldelli \& Schneider, 2012) and results of the size of shadow economy obtained using different estimation methods (Pickhardt \& Sarda Pons, 2006; Schneider, 2007; Schneider \& Buehn, 2013; Schneider et al., 2015). Application of different traditional shadow economy estimation methodologies is based on consideration of a variety of shadow economy reflectors including monetary (denomination of bank notes, cash contribution ratio, currency ratio/demand), income and expenditure (GDP discrepancies, income/expenditure discrepancies, consumer expenditure), and non-monetary (electricity consumption data, the number of small and medium enterprises, employment (labour) discrepancies) ones (Buehn \& Schneider, 2012; Georgiou, 2007; Schneider \& Williams, 2013; Schneider et al., 2015 and others).

The most modern models of shadow economy estimation (for instance, MIMIC) consider such variables as direct taxation, indirect taxation and social security contribution, state regulation, tax morale, unemployment quota, GDP per capita, employment quota, average working time and change of local currency. According to Schneider and Buehn, it is based on "the statistical theory of unobserved variables, which considers multiple causes and multiple indicators of the phenomenon to be measured" (2013: 18). However, the variable of digital shadow economy is not considered as one of the unobserved variables. Hence, the analysis of the scientific literature proposes that the methods applied for estimation of the size of traditional shadow economy do not reflect the size of digital shadow economy, which determines the necessity to identify which share in the total estimations of traditional shadow economy is generated by digital shadow economy.

On balance, digital shadow economy refers to unregistered or illegal, trade or service provision related, profitdriven activities online. However, since the activities including cybercrime, digital piracy or e-fraud stand for criminal offences rather than economic operations, they should be distinguished from the concept of digital shadow economy and left for purely criminal consideration. Hence, digital shadow economy should be treated as online service provision or trade that is deliberately concealed from public authorities seeking for economic or non-economic benefits. The analysis of the scientific literature has revealed that traditional methodologies of shadow economy estimation do not cover the indicators that would allow to estimate the level of digital shadow economy. For this reason, the aim of the empirical research is to establish plausible scopes of digital shadow economy and identify the sectors with the highest scopes of digital shadow economy in Lithuania over 2015.

Since to our knowledge this type of scientific analysis has been conducted for the first time, we employed the method of expert evaluation, and formulated the questions for the experts pursuing to obtain the information on 
their personal experience while detecting the cases of illegal activities in e-space. The methodology and results of the empirical research have been presented in the further sections of this article.

\section{The methodology of the research}

The analysis of the scientific literature has revealed that the scopes of traditional shadow economy are estimated by employing the variety of indicators, but the ones which reflect the size of digital shadow economy are not considered (see Figure 2).

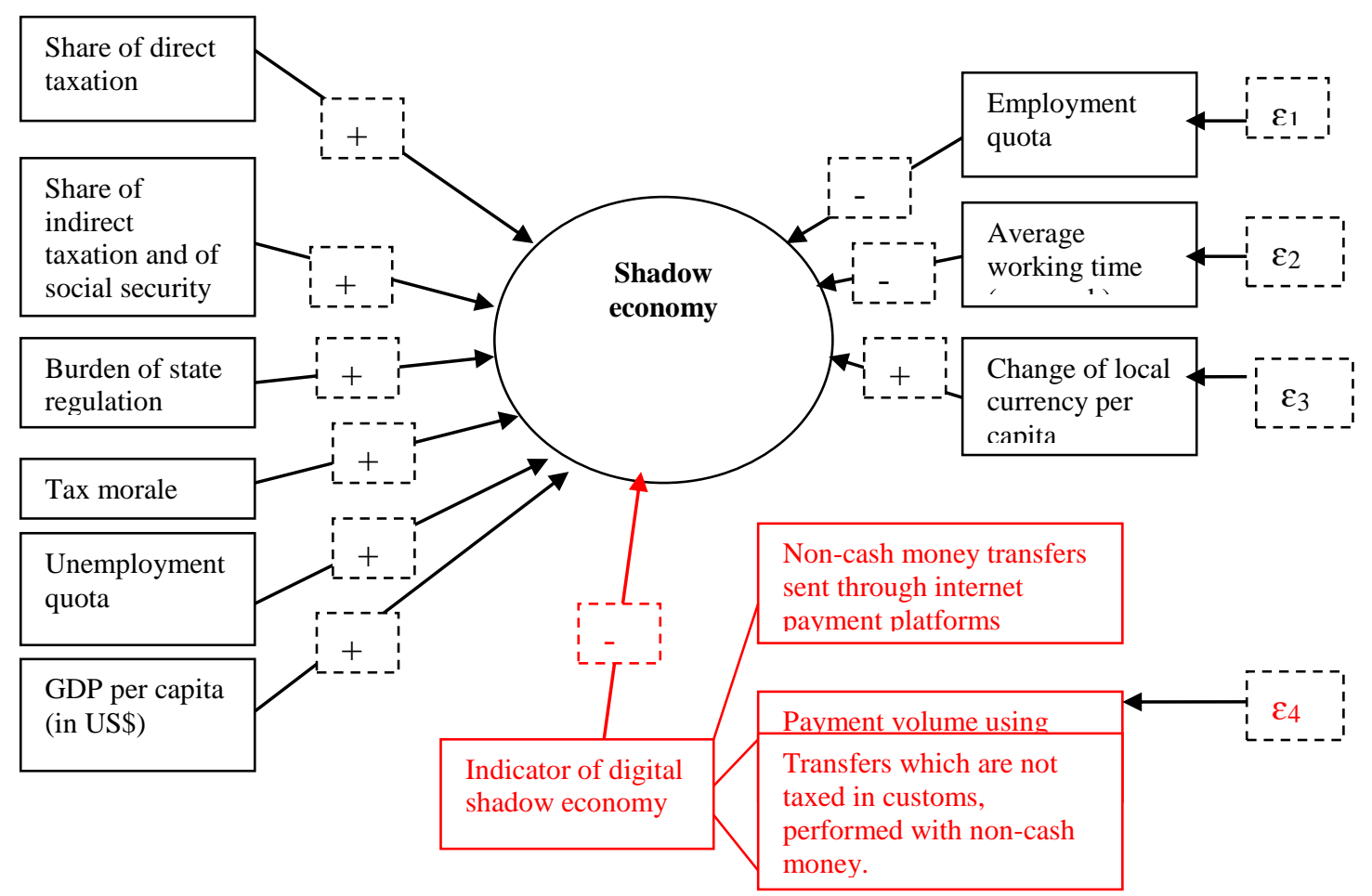

Fig.2. The variables of shadow economy estimation by MIMIC method updated with the indicator of digital shadow economy

Source: created by the authors with reference to Schneider et al., 2015.

After performance of the non-structural in-depth interviews with the heads of Lithuanian Department of Statistics and the Government of the Republic of Lithuania, the authors of this article propose to complement the MIMIC model, developed for estimation of the scopes of shadow economy, with the indicator of digital shadow economy that would be composed of non-cash transfers completed via online payment platforms like MoneyGram, Paysera, Mokipay, Paypal and others, frequency and amounts of payments in cryptocurrencies, and parcels delivered without custom duties (on the basis of non-cash transfers). During the interviews, the experts were asked to point out which of the following statistical indicators could compose an indicator developed to estimate the scope of digital shadow economy:

- $\quad$ amounts of trade in cryptocurrencies, EUR;

- non-cash flows in online payment platforms, EUR;

- amounts of goods from the third countries seized in customs for the avoidance/unwillingness to pay duties, EUR;

- amounts of money won at online casinos, poker sites, etc.

- amounts of money won in e-games. 
The interviews helped to find out that an indicator of digital shadow economy could be composed of several structural components (see Figure 2). In this research, the authors selected the method of expert evaluation for estimation of the scope of digital shadow economy in Lithuania. The research based on this method, has to involve $10-100$ experts, considering the primary purpose of the research as well as the competence of the experts in the researched field (Augustinaitis et al. 2009). The expert evaluation was carried out applying an indirect method of data collection - a questionnaire survey; the questionnaire for the survey was prepared in advance. Apart from creativity, attitude towards the expertise, judgement flexibility, reliability, self-criticism and related qualities, scientific literature (Augustinaitis et al. 2009) emphasises the significance of expert competence.

Representatives of the Department of Control under the State Tax Inspectorate, who are responsible for business control and examination processes, were involved in the research as experts. Before completion of the questionnaire, we conducted a pilot survey on the current situation of digital shadow economy estimation and the proposed formulation of the questions for further research (representatives of the Parliament of the Republic of Lithuania, the Government of the Republic of Lithuania, Chamber of Audit and the Department of Support and Audit under the State Tax Inspectorate agreed to participate in the pilot survey). The pilot survey also enabled to formulate the concepts of "traditional shadow economy", "digital shadow economy", "e-space" and "the Internet". Following the recommendations of the pilot survey experts, we familiarized the experts of the research introduced in this article with the concepts of "traditional shadow economy", "digital shadow economy", "espace" and "the Internet":

- traditional shadow economy refers to the processes ongoing in legally regulated markets, when these processes have a negative impact on state's revenue from taxes and cover illegal activities performed with avoidance of tax obligations or aiming at other illegal benefits related to tax avoidance;

- digital shadow economy refers to illegal activities, such as digital service provision and sales of goods/services in the Internet, performing which entities violate existent legal norms and regulations with a pursuit of illegal mutual interest and material benefits, exceptionally exploiting digital space;

- the term of e-space is linked to the terms of "the Internet", "cyberspace" and "electronic environment". All these terms refer to the non-physical virtual space, which was created by employing IT. Such space enables direct (online) communication among the participants of the global market.

- the Internet refers to the "net of networks", which combines huge quantities of computers all over the world and enables information exchange; exploitation of such network allows to significantly reduce communication costs for the people in different parts of the world. In the cyberspace, information can be transferred without any borders.

Analysis and interpretation of the research results. The questionnaire developed for this research consisted of 8 questions and was compiled by employing Google questionnaire creation tools. The first question enabled to establish in which Lithuanian district the largest part of the experts work. The second question - "How many cases, when physical entities performed economic activities in e-space without registration of these activities and without declaration of the revenues generated from these acitivities to the State Tax Inspectorate, did you detect over 2015?" - was included with the aim to disclose the plausible scope of digital shadow economy which was captured during the inspections. The third question - "How many cases, when physical entities who have officially registered a traditional business, but at the same time run a business in e-space and hide the revenues earned from the latter, did you detect over 2015?" - was included in order to specify the plausible scope of digital shadow economy in the country over the researched period (we included this question following the recommendations of the pilot survey experts, who noted that entities may conduct shadow e-business alongside with an officially-registered traditional business). The fourth and fifth questions enabled to identify the sectors with the highest scopes of digital shadow economy in Lithuania over 2015. The other questions were included 
with the aim to obtain the plausible numerical estimation of unaccounted revenues earned in e-space in the country over the researched period and to identify the e-space objects that commonly lie under control of the State Tax Inspectorate of the Republic of Lithuania. The experts were asked to evaluate each of the statements in Likert evaluation scale, where rank 1 stands for the lowest (I completely disagree/it is completely insignificant), and rank 5 - for the highest possible evaluation (I completely agree/it is extremely significant). In accordance with the strength of agreement/disagreement with a particular statement, intermediate ranks 2, 3 or 4 could be selected. The results of the research were processed with SSPS (Statistical Package for Social Sciences) and Microsoft Excel software. The generalized rank values have been presented in Table 1.

Table 1. Matrix of the expert evaluation results on digital shadow economy concept, features and channels

\begin{tabular}{|c|c|c|c|c|c|c|}
\hline \multirow{2}{*}{ Experts } & \multicolumn{7}{|c|}{ Variables (V) } \\
\cline { 2 - 6 } & $\mathbf{1}$ & $\mathbf{2}$ & $\ldots$ & $\mathbf{i}$ & $\ldots$ & $\mathbf{N}$ \\
\hline 1 & $\mathrm{~V}_{11}$ & $\mathrm{~V}_{12}$ & $\ldots$ & $\mathrm{V}_{1 \mathrm{i}}$ & $\ldots$ & $\mathrm{V}_{1 \mathrm{n}}$ \\
\hline 2 & $\mathrm{~V}_{21}$ & $\mathrm{~V}_{22}$ & $\ldots$ & $\mathrm{V}_{2 \mathrm{i}}$ & $\ldots$ & $\mathrm{V}_{2 \mathrm{n}}$ \\
\hline$\ldots$ & $\ldots$ & $\ldots$ & $\ldots$ & $\ldots$ & $\ldots$ & $\ldots$ \\
\hline $\mathrm{J}$ & $\mathrm{V}_{\mathrm{j} 1}$ & $\mathrm{~V}_{\mathrm{j} 2}$ & $\ldots$ & $\mathrm{V}_{\mathrm{ji}}$ & $\ldots$ & $\mathrm{V}_{\mathrm{jn}}$ \\
\hline$\ldots$ & $\ldots$ & $\ldots$ & $\ldots$ & $\ldots$ & $\ldots$ & $\ldots$ \\
\hline $\mathrm{M}$ & $\mathrm{V}_{\mathrm{m} 1}$ & $\mathrm{~V}_{\mathrm{m} 2}$ & $\ldots$ & $\mathrm{V}_{\mathrm{mi}}$ & $\ldots$ & $\mathrm{V}_{\mathrm{mn}}$ \\
\hline Rank sum & & & & & & \\
\hline $\begin{array}{c}\text { Kendall's coefficient of concordance, } \\
W\end{array}$ & & & & & & \\
\hline p-value & & & & & & \\
\hline Frequency of feature indication & & & & & & \\
\hline
\end{tabular}

In Table 1, value $\mathrm{V}_{\mathrm{jn}}$ reflects the level of significance, which was attributed to statement $n$ by expert $\mathrm{j}$. By employing the introduced matrix, rank sum $\mathbf{V}_{\mathbf{i}}$ for statement $i$ as well as rank sum $\mathbf{S}_{\mathbf{i}}$ average $\bar{s}$ for statement $i$ were estimated, and significance of each of the statements alongside with compatibility of the experts' opinions (expressed as Kendall's coefficient of concordance W) were established. Variability of Kendall's coefficient of concordance falls into the interval $0 \leq \mathrm{W} \leq 1$, which means that the values of the coefficient close to 1 show high compatibility of the experts' opinions. When $\mathrm{W} \leq 0.6$, compatibility of the expert evaluation results is considered weak, but if $\mathrm{p}<0.05$, the data can be treated as reliable.

When introducing the results of the expert evaluation, special attention should be drawn to interpretation of Cronbach alpha coefficient. Some scientists, e.g. Nunnally and Bernstein (1994), point out that Cronbach alpha coefficient must be higher than 0.7. The research was conducted by the Internet over January and February, 2016. 184 experts participated in the research. The results of the research were processed by employing SSPS and Microsoft Excel software.

\section{The results of the empirical research: the scope of digital shadow economy in Lithuania}

Systematisation of the research results has disclosed that the experts working in Vilnius and Kaunas Departments of Control under the State Tax Inspectorate of the Republic of Lithuania composed the largest part of the total number of the respondents (respectively 31.7 and 25.7 percent). Active involvement of the experts from the above-mentioned Lithuanian cities must have been determined by the largest overall population in these cities. The share of the experts working in Siauliai and Panevezys Departments of Control under the State Tax Inspectorate composed respectively 18.6 and 17.5 percent (see Figure 3). 


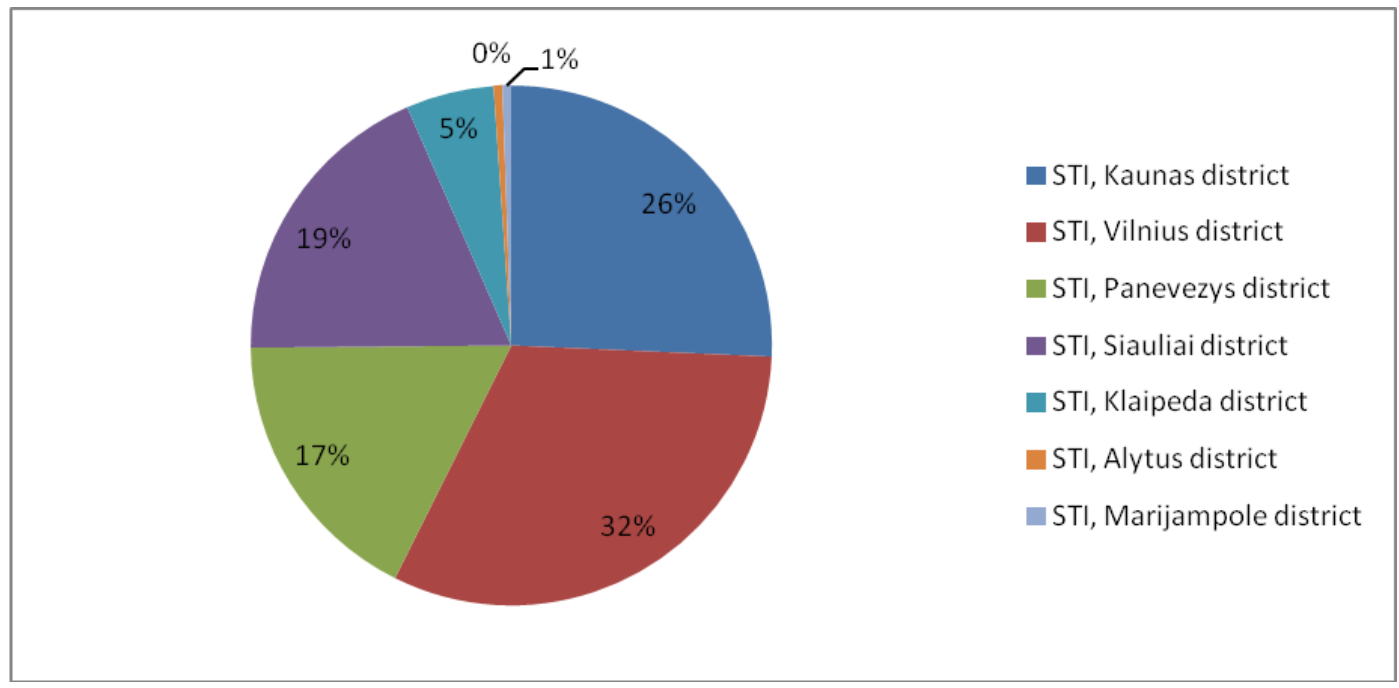

Fig.3. Distribution of the experts by geographical region

Source: Compiled by the authors with reference to the research results.

Further in the survey, the experts answered the questions which were included in order to estimate the scope of shadow economy in Lithuania over 2015. The data in Table 1 show that more than a half of the experts (i.e. 52.6 percent of the total number of the respondents) have never checked or received an order to check the subjects who constantly operate in e-space without declaration of their revenues to the State Tax Inspectorate.

Table 2. Estimation of the scope of digital shadow economy

\begin{tabular}{|c|c|}
\hline Question & Substantiation \\
\hline $\begin{array}{l}\text { 1) How many cases, when physical entities } \\
\text { performed economic activities in e-space } \\
\text { without registration of these activities and } \\
\text { without declaration of the revenues } \\
\text { generated from these acitivities to the State } \\
\text { Tax Inspectorate, did you detect over } \\
2015 \text { ? }\end{array}$ & $\begin{array}{l}36.6 \text { percent of the experts marked that they had detected up to } 2 \\
\text { percent of the total number of traditional shadow economy cases, } \\
\text { when physical entities performed economic activities in e-space } \\
\text { without registration of these activities and without declaration of the } \\
\text { revenues generated from these acitivities to the State Tax } \\
\text { Inspectorate. Insignificant number of the experts (from } 1 \text { to } 6 \text { people) } \\
\text { indicated that the cases of digital shadow economy make } 2-11 \\
\text { percent of the total number of traditional shadow economy cases. } \\
\text { Note: } 52.6 \text { percent of the experts selected the answer alternative } \\
\text { "Others", and substantiated their selection with such reasons as } \\
\text { absence of the orders to check economic acitivities performed by } \\
\text { physical entities in e-space over } 2015 \text {; the cases of digital shadow } \\
\text { economy were not detected because the experts did not face such } \\
\text { cases; the period of } 2015 \text { was indicated as non-reference period. }\end{array}$ \\
\hline $\begin{array}{l}\text { 2) How many cases, when physical entities } \\
\text { who have officially registered a traditional } \\
\text { business, but at the same time run a } \\
\text { business in e-space and hide the revenues } \\
\text { earned from the latter, did you detect over } \\
2015 \text { ? }\end{array}$ & $\begin{array}{l}33.6 \text { percent of the experts marked that, in the total number of } \\
\text { shadow economy cases, they had detected up to } 2 \text { percent of the cases } \\
\text { when physical entities who have officially registered a traditional } \\
\text { business, but at the same time run a business in e-space and hide the } \\
\text { revenues earned from the latter. Insignificant number of the experts } \\
\text { (1-4 people) noted that this percentage could compose } 2-11 \text { percent in } \\
\text { the total number of shadow economy cases. } \\
\text { Note: } 53.9 \text { percent of the experts selected the answer alternative } \\
\text { "Others", and substantiated their selection with such reasons as } \\
\text { "the expert did not face such cases" and "no control procedures } \\
\text { in e-space took place over 2015". }\end{array}$ \\
\hline
\end{tabular}




\begin{abstract}
3) How many cases, when physical entities ran a traditional business without registration of this business and without declaration of the revenues generated from this business to the State Tax Inspectorate, did you detect over 2015?
\end{abstract}

\begin{abstract}
41.3 percent of the experts marked that, in the total number of shadow economy cases, they had detected up to 2 percent of the cases when physical entities ran a traditional business without registration of this business and without declaration of the revenues generated from this business to the State Tax Inspectorate. 8.4 percent of the experts detected 2-4 percent of such cases, 5.6 percent of the experts - 4-6 percent of such cases; and 3 percent of the experts - 6-11 percent of such cases.

Note: 39.9 percent of the experts selected the answer alternative "Others", and substantiated their selection with such reasons as "the expert did not face such cases" and "the period of 2015 was considered a non-reference period".
\end{abstract}

Source: compiled by the authors with reference to the results of the expert evaluation.

The rest part of the experts (36.6 percent of the total number of the respondents) indicated that they had detected up to 2 percent of the total number of shadow economy cases in e-space.

Further in the research, we asked the experts to note whether they had dealt with the cases when a person had officially registered a traditional business, but at the same time runs business in e-space and hides the revenues earned from the latter. The research has disclosed that 53.9 percent of the experts have never faced this problem, and 2015 was not a reference year of control; 33.6 percent of the experts have detected up to 2 percent of entrepreneurs who hide their revenues earned from business in e-space.

In order to obtain the numerical value of the scope of digital shadow economy (million euros) in Lithuania, we asked the experts to indicate the plausible scope of unaccounted revenues generated in e-space over 2015 (see Figure 4).

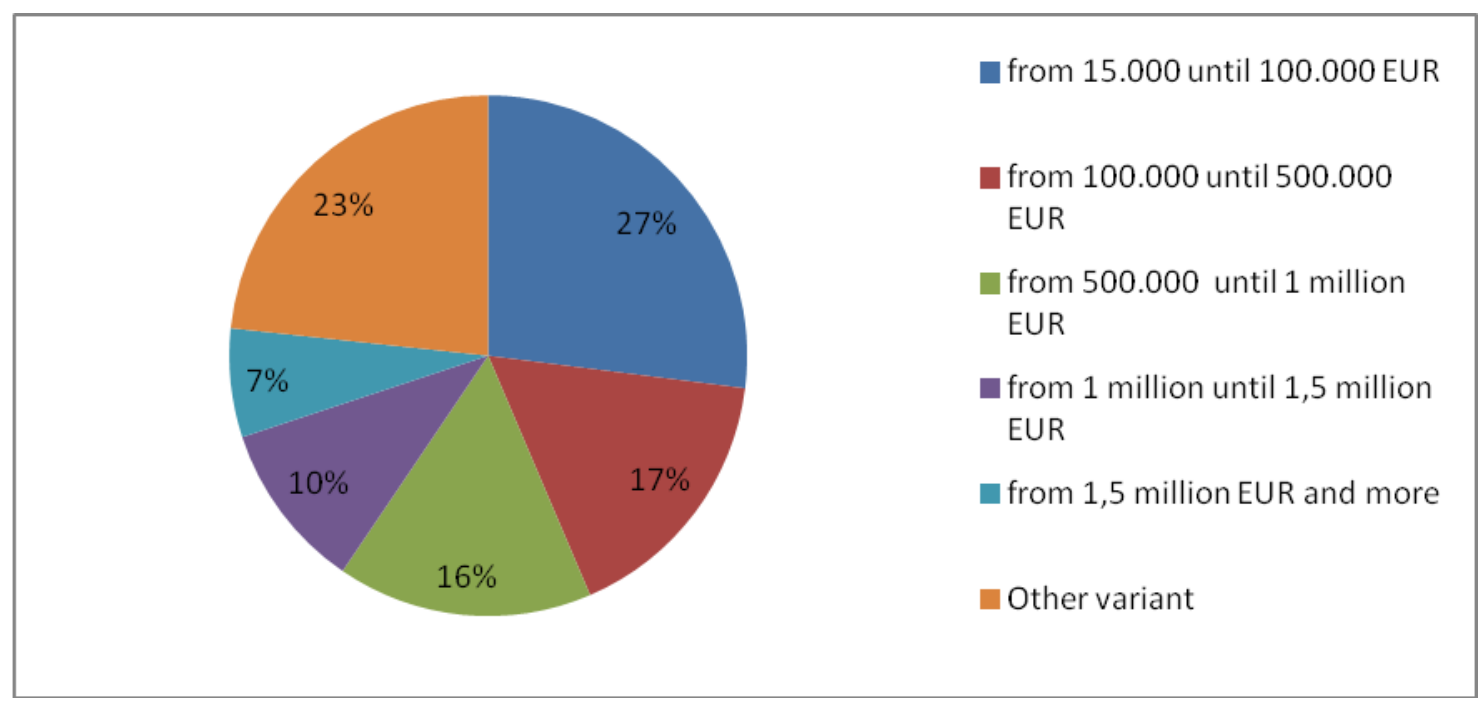

Fig.4. The numerical value of the plausible scope of digital shadow economy in Lithuania over 2015, million euros

Source: compiled by the authors with reference to the research results.

The data in Figure 3 show that distribution of plausible scopes of unaccounted revenues, generated in e-space over 2015, is nearly equal for all the scope intervals, i.e. the plausible scope of digital shadow eonomy in Lithuania over 2015 varies from 15 thousand to 1.5 million euros and more. Nevertheless, the majority of the 
experts noted that the plausible scopes of digital shadow economy in Lithuania over the researched period might vary from 15 to 100 thousand euros.

Alongside with the plausible scope of digital shadow economy, we attempted to identify the areas of economic activities (by Lithuanian Classification of Economic Activities EVRK 2) with the highest scopes of undeclared revenues generated in e-space. The value of Cronbach alpha coefficient equal to 0.82 shows that the questions presented to the experts reflect the researched dimension with appropriate accuracy. The value of Kendall's coefficient of concordance is equal to 0.122 , but value $\mathrm{p}$ equal to 0.000 refers to statistically significant answers, although compatibility of the experts' opinions is weak. We consider an economic activity significant if its mean rank is equal to or higher than 3.5 points (see Figure 5).

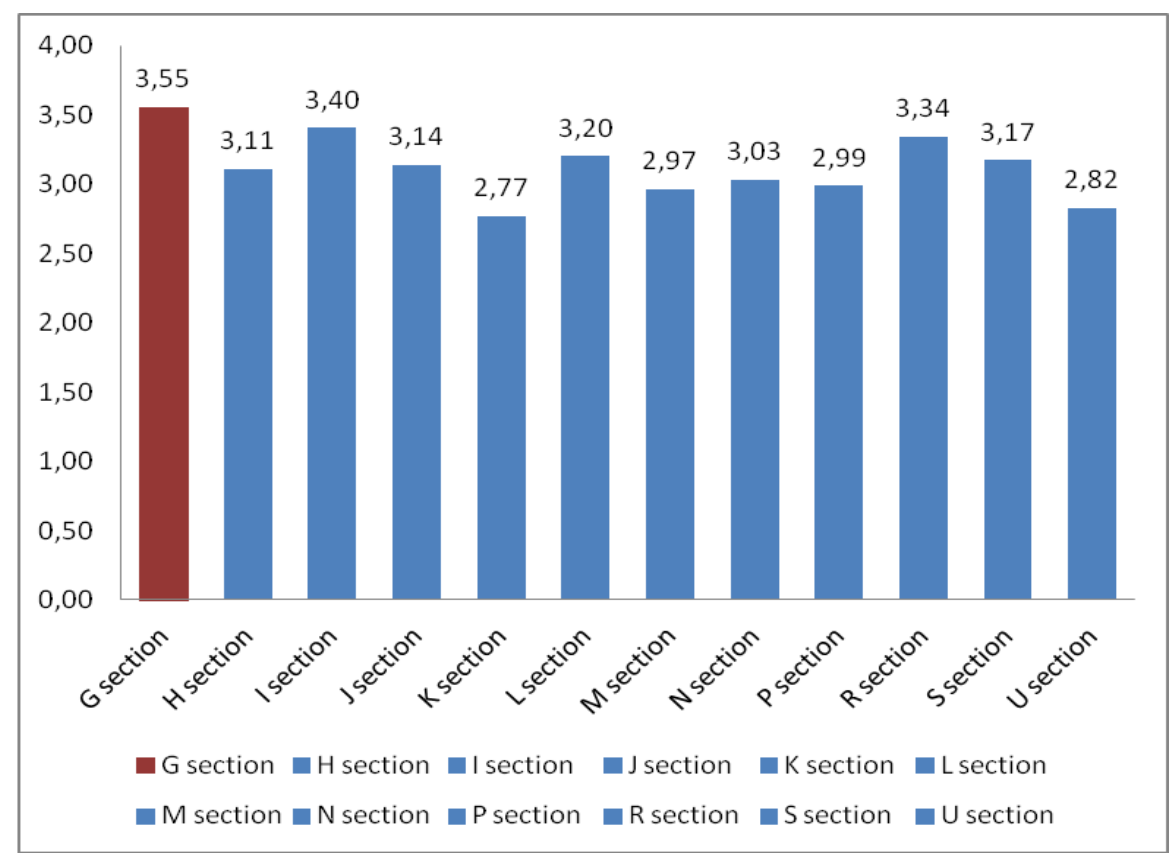

Fig.5. Experts' position on the areas of economic activities with the highest scopes of undeclared revenues generated in e-space

Source: compiled by the authors with reference to the research results.

The data presented in Figure 4 show that section $G$ - wholesale and retail; repair of motor vehicles and motorcycles - is the only section with captured cases of digital shadow economy (mean rank is equal to 3.5). Mean ranks estimated for the other sections of economic activities range around 3, which proposes that either the cases of digital shadow economy in these sections have not been captured or the scopes of digital shadow economy are insignificant there.

Further in the research, we asked the experts to indicate the types of products/services which are illegally traded in each of the sections to earn unaccounted revenue in e-space. With reference to the research results, we can distinguish the following types of such products/services:

- Car trade and services (vehicle trade, car parts, transportation services, taxi services);

- Services of construction sector (rent of premises, accommodation services, real estate rent);

- Catering (food preparation, bakery (cakes), food delivery to different types of events);

- Trade in clothing, footwear, domestic electric appliances, electronic devices, perfumery, cosmetics, food supplements, energy resources to physical entities (wood, wood pellets), timber, building materials; 
- Education services (assistance with preparation of reference papers, diploma works, tutorial services, language teaching, informal education circles);

- Beauty and entertainment services (massages, beauty services, rest and recreation arrangement services, travel arrangement);

- Advertisement services, administration of websites.

The research results have also revealed which e-space objects commonly lie under control of the State Tax Inspectorate of the Republic of Lithuania (see Figure 6).

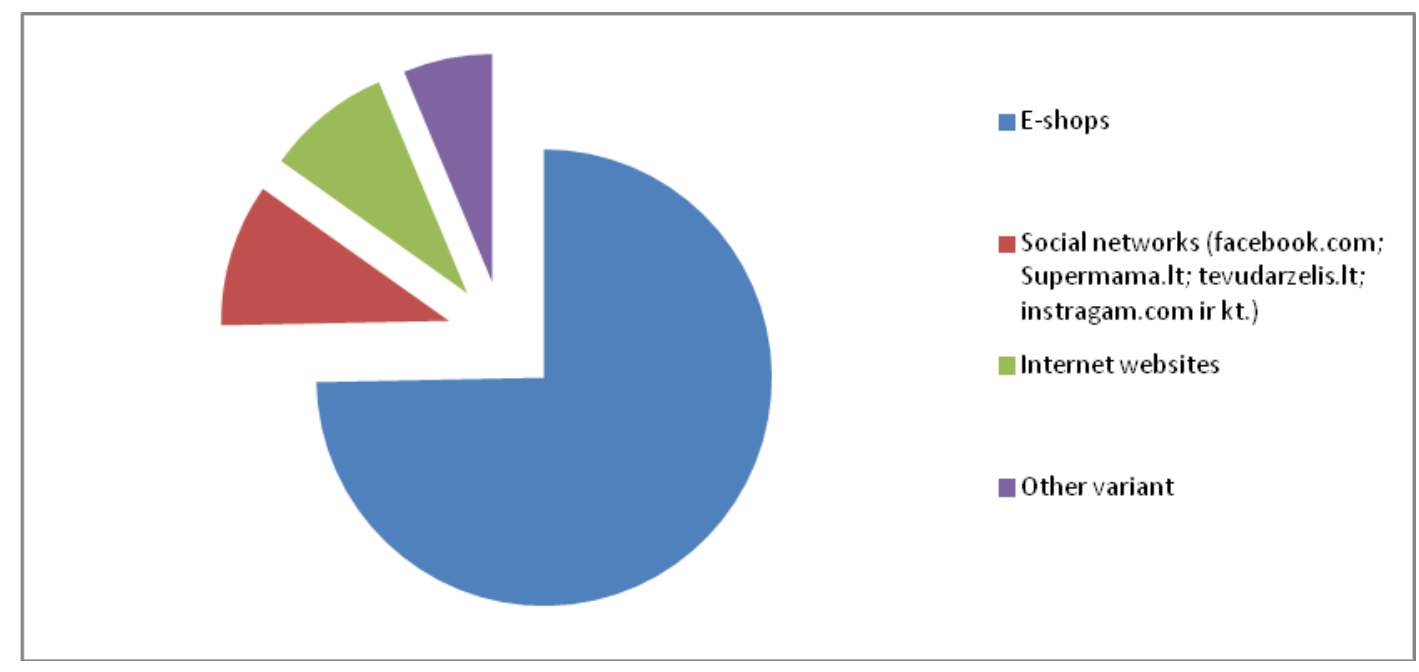

Fig.6. E-space objects which commonly lie under control of the State Tax Inspectorate, percent

Source: compiled by the authors with reference to the research results.

The data presented in Figure 6 show that e-shops are the objects that most commonly lie under control of the State Tax Inspectorate of the Republic of Lithuania, as it was noted by 74.7 percent of the experts. 10.1 percent of the experts control social networks, and 8.9 percent of the experts - internet websites.

The results of the research lead to the following conclusions:

1) Estimation of the scope of digital shadow economy is a topical issue of economics and tax evasion not only in Lithuania, but also in other Eastern EU Member-States, and no clear strategical guidelines have been defined to solve this problem. We make this conclusion with reference to the research results, which have revealed that over the year 2015 , more than a half (52.6 percent) of the experts did not check or receive an order to check the subjects who constantly operate in e-space without declaration of their revenues to the State Tax Inspectorate. Also, 53.9 percent of the experts admitted having never dealt with the cases when a person has officially registered a traditional business, but at the same time runs business in e-space and hides the revenues earned from the latter. This proposes that the Department of Control under the State Tax Inspectorate of the Republic of Lithuania either do not possess sufficient human and financial resources to detect the cases of illegal economic activities in e-space or do not have any efficient mechanisms which would enable to do it. Hence, the improvement of the situation calls for the development of additional competences and skills in IT and law areas, and raises the necessity to attract extra funding for acquisition of the software which would allow to detect and identify illegal economic activities (operations) in e-space.

2) The results of the expert evaluation have disclosed that authorized officials detected up to 2 percent of the total number of shadow economy cases in e-space in Lithuania over 2015. The areas of economic activities with the highest scopes of undeclared revenues generated in e-space cover wholesale and retail, 
and repair of motor vehicles and motorcycles (mean rank is equal to 3.5). The types of products/services which are illegally traded in each of the sections to earn unaccounted revenue in e-space include real estate rent and sales, education and catering services, trade in clothing, vehicles and electronic devices. The plausible scope of digital shadow economy in Lithuania over 2015 varies from 15 thousand to 1.5 million euros and more, which shows that deviation of the plausible numerical value of the scope of digital shadow economy in the country is extremely high.

3) The objects that most commonly lie under control of the State Tax Inspectorate of the Republic of Lithuania include e-shops, while social networks and internet websites are controlled to the smallest extent, which proposes that they make the most favourable environment for the development of digital shadow economy.

4) The methodologies aimed at estimation of the scope of digital shadow economy have not been developed; the Department of Control under the State Tax Inspectorate of the Republic of Lithuania attribute the identified cases of digital shadow economy to the total number of the cases of shadow economy in the country. Due to this reason, it is difficult to capture the true data on the scopes and trends of digital shadow economy. Hence, inclusion of the indicators of digital shadow economy in the methodologies of shadow economy estimation would enable to obtain the data on the real volumes of this phenomenon and would contribute to the development of the measures aimed at digital shadow economy detection and prevention.

\section{Summary and conclusions}

The analysis of the scientific literature has revealed that digital shadow economy refers to unregistered or illegal, trade or service provision related and profit-driven activities online. However, considering the offensive nature of such activities as cybercrime, digital piracy or e-fraud, they should be distinguished from the concept of digital shadow economy and left for purely criminal consideration. Hence, digital shadow economy should be treated as online service provision or trade that is deliberately concealed from public authorities seeking for economic or non-economic benefits.

The analysis of the scientific literature has also disclosed that traditional methodologies of shadow economy estimation do not cover the indicators that would allow to estimate the level of digital shadow economy, which determines the necessity to identify which share in the total estimations of traditional shadow economy is generated by digital shadow economy. The improved model of shadow economy estimation (based on the MIMIC model) that covers the indicator of digital shadow economy requiring additional statistics, which are not accumulated in traditional statistical databases, is a contribution to the development of the theory of shadow economy. Since to our knowledge this type of scientific analysis has been conducted for the first time, we employed the method of expert evaluation for the empirical research.

The empirical research, based on the method of expert evaluation, has enabled to establish the plausible scopes of digital shadow economy and identify the areas of economic activities with the highest scopes of undeclared revenues in Lithuania. With reference to the empirical research, the following conclusions can be made:

1. The scopes of digital shadow economy are not captured or estimated separately from the scopes of traditional shadow economy. The majority of the authorized officials from the Department of Control under the State Tax Inspectorate of the Republic of Lithuania do not check or receive an order to check the subjects who constantly operate in e-space without declaration of their revenues to the State Tax Inspectorate, and do not deal with the cases when a person has officially registered a traditional business, but at the same time runs business in e-space and hides the revenues earned from the latter. These findings propose that the institutions authorised to deal with the cases of shadow economy do not possess sufficient human and financial resources to detect the cases of illegal economic activities in e-space or do 
not have any efficient mechanisms which would enable to do it. Hence, estimation of the scope of digital shadow economy remains a topical issue of economics and tax evasion, and the improvement of the situation calls for the development of additional competences and skills in IT and law areas, and raises the necessity to attract extra funding for acquisition of the software which would allow to detect and identify illegal economic activities (operations) in e-space.

2. The plausible scope of digital shadow eonomy in Lithuania over 2015 varies from 15 thousand to 1.5 million euros and more, which shows that deviation of the plausible numerical value of the scope of digital shadow economy in the country is extremely high, although the majority of the experts note that the plausible scopes of digital shadow economy in Lithuania over the researched period may vary from 15 to 100 thousand euros.

3. The areas of economic activities with the highest scopes of undeclared revenues generated in e-space cover wholesale and retail, and repair of motor vehicles and motorcycles (mean rank is equal to 3.5). The types of products/services which are illegally traded in each of the sections to earn unaccounted revenue in e-space include real estate rent and sales, education and catering services, trade in clothing, vehicles and electronic devices.

On balance, we can state that attribution of the figures of digital shadow economy to the total estimations of shadow economy impedes capturing the real data on the scopes and trends of digital shadow economy. Hence, inclusion of the indicators of digital shadow economy in the methodologies of shadow economy estimation would enable to obtain the data on the real volumes of this phenomenon and would contribute to the development of the measures aimed at digital shadow economy detection and prevention.

\section{References}

Amasiatu, C. V., \& Shah, M. H. 2014. First party fraud: a review of the forms and motives of fraudulent consumer behaviours in e-tailing. International Journal of Retail \& Distribution Management, 42(9): 805-817.

Arli, D., Tjiptono, F., \& Porto, R. 2015. The impact of moral equity, relativism and attitude on individuals' digital piracy behaviour in a developing country. Marketing Intelligence \& Planning, 33(3): 348-365.

Augustinaitis, A.; Rudzkienè, V.; Petrauskas, R.; Dagyte, I.; Martinaitytė, E.; Leichteris, E.; Malinauskienė, E.; Višnevska, V.; Žilionienė, I. 2009. Lietuvos e. valdžios gairès: ateities įžvalgų tyrimas: kolektyvinè monografija. Vilnius: Mykolas Romeris University Publishing Centre.

Bossler, A. M., \& Holt, T. J. 2012. Patrol officers' perceived role in responding to cybercrime. Policing An International Journal of Police Strategies \& Management, 35(1): 165-181. doi: 10.1108/13639511211215504.

Buehn, A., \& Schneider, F. 2012. Shadow economies around the world: novel insights. International Tax and Public Finance, 19(1): 139171.

Camarero, C., Anton, C., \& Rodriguez, J. 2014. Technological and ethical antecedents of e-book piracy and price acceptance: evidence from the Spanish case. The Electronic Library, 32(4): 542-566. doi: 10.1108/EL-11-2012-0149.

Castro, D., Bennett, R., \& Andes, S. 2009. Steal these policies: strategies for reducing digital piracy. http://www.itif.org/publications/stealthese-policies-strategies-reducing-digital-piracy. Accessed 17 October 2015.

Delina, R. Tkáč, M. 2015. Role of e-business in the perception of ICT impact on revenue growth. Journal of Business Economics and Management, 16(6): 1140-1153. doi: 10.3846/16111699.2013.797012.

Georgiou, G. M. 2007. Measuring the size of the informal economy: a critical review. http://www.centralbank.gov.cy/media/pdf/npwpe_no1_052007__.pdf. Accessed 11 November 2015.

Government Accounting Office. 2007. Cybercrime: Public and Private Entities Face Challenges in Addressing Cyber Threats. http://www.gao.gov/new.items/d07705.pdf. Accessed 10 October 2015. 
Hanclova, J.; Doucek, P.; Fischer, J.; Vltavska, K. 2015. Does ITC capital effect economic growth in the EU-15 and EU-12 countries? Journal of Buiness Economics and Management, 16(2): 387-406. http:/dx.doi.org/10.3846/16111699.2012.754375

Harris, L. C., \& Daunt, K. L. 2011. Deviant customer behaviour: a study of techniques of neutralisation. Journal of Marketing Management, 27(7-8): 834-853.

Herley, C., \& Florencio, D. 2010. Nobody sells gold for the price of silver: Dishonesty, uncertainty and the underground economy. http://link.springer.com/chapter/10.1007\%2F978-1-4419-6967-5_3\#page-1. Accessed 11 October 2015.

Hjort, K., \& Lantz, B. 2012. (R)e-tail borrowing of party dresses: an experimental study. International Journal of Retail \& Distribution Management, 40(12): 997-1012.

Holt, T. J., Blevins, K. R., \& Burkert, N. 2010. Considering the paedophile subculture on-line. Sexual Abuse: Journal of Research and Treatment, 22(1): 3-24.

Holz, T., Engelberth, M., \& Freiling, F. 2012. Learning more about the underground economy: a case-study of keyloggers and dropzones. ESORICS Proceedings, 9: 1-18.

Mayayise, T., \& Osunmakinde, I. O. 2014. E-commerce assurance models and trustworthiness issues: an empirical study. Information Management \& Computer Security, 22(1): 76-96. doi: 10.1108/IMCS-01-2013-0001.

Mello, J. P. 2013. Cybercrime fuelled by mature digital underground. http://www.csoonline.com/article/2133649/identityaccess/cybercrime-fueled-by-mature-digital-underground.html. Accessed 10 October 2015.

Nunnally, J. C.; Bernstein, I. H. 1994. Psychometric theory. 3rd ed. New York: McGraw-Hill.

Pickhardt, M., \& Sarda Pons, J. 2006. Size and scope of the underground economy in Germany. Applied Economics, 38(4): 1707-1713.

Reynolds, K. L., \& Haris, L. C. 2009. Dysfunctional customer behavior severity: an empirical examination. Journal of Retailing, 85(3): 321-335.

Schneider, F. 2007. Shadow Economies and Corruption All Over the World: New Estimates for 145 Countries. Economics, 9: 3-47.

Schneider, F., \& Buehn, A. 2013. Estimating the size of the shadow economy: methods, problems and open questions. http://www.economics.jku.at/papers/2013/wp1320.pdf. Accessed 14 November 2015.

Schneider, F., \& Williams, C. C. 2013. The Shadow Economy. London: The Institute of Economic Affairs.

Schneider, F., Raczkowski, K., \& Mróz, B. 2015. Shadow economy and tax evasion in the EU. Journal of Money Laundering Control, 18(1): 34-51. doi: 10.1108/JMLC-09-2014-0027.

Smaliukiene, R.; Chi-Shiun, L.; Sizovaite, L. 2015. Consumer value co-creation in on-line business: the case of global travel services. Journal of Business Economics and Management, 16(2): 325-339. http://dx.doi.org/10.3846/16111699.2014.985251

Smith, G. S. 2015. Management models for international cybercrime. Journal of Financial Crime, 22(1): 104-125.

Swire, P. 2009. No cop on the beat: underenforcement in e-commerce and cybercrime. Journal of Telecommunications and High Technology Law, 7(1): 107-26.

Taylor, S. A. 2012. Evaluating digital piracy intentions on behaviors. Journal of Services Marketing, 26(7): $472-483$.

Teobaldelli, D. 2011. Federalism and the Shadow Economy. Public Choice, 146(3): 269-269.

Teobaldelli, D., Schneider, F. 2012. Beyond the veil of ignorance: The influence of direct democracy on the shadow economy. http://www.econ.jku.at/members/Schneider/files/publications/2012/Teobaldelli.pdf. Accessed 21 October 2015.

Vlachos, V., Minou, M., Assimakopouos, V., \& Toska, A. 2011. The landscape of cybercrime in Greece. Information Management \& Computer Security, 19(2): 113-123. 
The International Journal

ENTREPRENEURSHIP AND SUSTAINABILITY ISSUES

ISSN 2345-0282 (online) http://jssidoi.org/jesi/

2016 Volume 4 Number 2 (December)

Wall, D. S., \& Williams, M. 2007. Policing diversity in the digital age: maintaining order in virtual communities. Criminology and Criminal Justice, 7(4): 391-415.

Zorz, M. 2015. Global black markets and the underground economy. http://www.net-security.org/article.php?id=2288. Accessed 12 October 2015.

Prof. Dr. Ligita GASPARÉNIENE் links her research fields to the analysis of macroeconomic phenomenon's, practical decisions of outsourcing and estimation of shadow economy. In 2009, she defended the doctoral thesis on the topic "The impact on transaction costs on outsourcing contracts" (the field of economics, social sciences). During the period of 2005-2015, the researcher has published over 40 scientific articles and issued two monographs titled "The methodology of the estimation of external service transaction costs" and "Estimation of financial investment and investment projects". The basic fields of her scientific work include transaction costs, shadow economy, real estate economy. Ligita Gaspareniene participated in 3 chartered national projects and is currently involved in the scientific national (Lithuanian) project "Digital shadow economy" as the principal researcher.

ORCID ID 0000-0002-5535-6552

Assoc. Prof. Dr. Rita REMEIKIENE் has accumulated much scientific experience in the research of self-employment and business environment conditions in transition economies. In 2012, she defended the doctoral thesis on the topic "The factors of self-employment in transition economies" (the field of economics, social sciences), which won Lithuanian Science Council's award for the best research in the field social sciences. During her scientific career, Rita Remeikienè has prepared and published over 40 scientific articles (6 of which were included in ISI basic list issues; 7 - in ISI database referred issues; 14 - in international databases referred issues, etc.). The main topics of the research are linked to the issues of expansion of opportunities in the labour market, shadow economy, outsourcing, gender gaps, and entrepreneurship. Previously, Rita Remeikienè participated in 3 chartered national projects and led the study project "Nord Plus Horizontals". At present, she is leading the scientific national (Lithuanian) project "Digital shadow economy".

ORCHID ID: 0000-0002-3369-485X

Alius SADECKAS is researcher (PhD student) at Mykolas Romeris University. Research interests: organization theory, complex, quantitative evaluation of social processes and phenomena; economic systems, shadow economy.

Prof. dr. habil. Romualdas GINEVIČIUS is the head of Department of Enterprise Economics and Management, construction engineer and economist. The author of more than 350 research papers and over 20 scientific books; Editor-in-Chief of the „Journal of Business Economics and Management" (Thomson Reuters, "Web of Science“) and the journal „Business: Theory and Practice“ (SCOPUS). Research interests: organization theory, complex, quantitative evaluation of social processes and phenomena.

Copyright (C) 2016 by author(s) and VsI Entrepreneurship and Sustainability Center

This work is licensed under the Creative Commons Attribution International License (CC BY).

http://creativecommons.org/licenses/by/4.0/

cC) (i) Open Access 